\title{
Health Capital, Primary Health Care and Economic
}

\section{Growth}

\author{
Tengiz Verulava
}

Health Policy and Insurance Institute, School of Business, Ilia State University

\begin{abstract}
Investments in healthcare are important in terms of formation of the health capital. The research aims to find out the role of the health capital in economic growth of Georgia (country).

This study is based on the secondary sources of data. The study data were obtained from Human Development Report, Ministry of Labor, Health and Social Protection of Georgia. As a proxy indicator for measuring the health capital we used the life expectancy, the morbidity prevalence and Incidence rate, maternal and children's mortality rate, outpatient referral rate, the state expenses on healthcare.

The average life expectancy has increased in recent 25 years. The maternal and children's mortality rate has decreased, healthcare expenses have become higher and outpatient referral rate has also become more constant character. All these have a positive influence on the people's health and country's economic growth. However, the state expenses on health and primary healthcare referral rate is far below the European level. Patients are less motivated to go to a primary healthcare for prevention and decide to receive medical service only when they are in critical condition. All this shows that the primary healthcare system cannot fulfill the role of the so-called 'gatekeeper'. In general, the primary healthcare system has not developed in Georgia.

As the health capital fulfills significant role in terms of the country's economic growth in a long-run perspective, it is advisable to promote the development of the primary healthcare system and taking WHO recommendations concerning state healthcare expenses into account.
\end{abstract}

Key Words: Health capital, human capital, primary care, economic growth

\section{Introduction}

According to the OECD, human capital is defined as: "the knowledge, skills, competencies and other attributes embodied in individuals or groups of individuals acquired during their life and used to produce goods, services or ideas in market circumstances" (1).

The human capital concept was elaborated in the 1960s. T. Schulz was the first to use the term 'human capital' in which he implied a combination of investments in a human being that improve his/her working capacity (2). Schulz's ideas were further developed by the so-called 'Chicago School' representatives (G. Baker, P. Bowen, E. Hansen) who have established the main assumptions of the human capital concept. According to the Nobel Prize Laureate G. Baker 'the human capital represents a combination of innate capabilities as well as acquired skills, knowledge and motivation that are used for producing goods and services and represent a source of human and social income' (3). Becker observes that investments in human capital should fall with age as the period over which returns can be accrued decreases; Yet, investments in health clearly increase with age, even after retirement when health has lost its importance in generating earnings (4).

Initially, education was considered to be the main factor in the human capital formation. In 1970s, M. Grossman presented the health capital role according to which a person is interested in increasing his future incomes due to investments in education and health (3). Consequently, human productivity increases and causes economic growth in turn (4).

The health capital implies investments in a human being that are necessary for maintaining his health and capacity. Health influences a person's wellbeing. It represents the goods that can be consumed as well as invested. Health, as the consumable good, implies that it gives pleasure to a person. Thus, health, as the consumable goods is required. Health, as an investment advantage means that a person is able to work and make 
incomes. The health investment advantage is determined with the value of the benefit received as a result of the advantage. For example, the life expectancy growth means additional years of work through which a human being receives incomes and invests in his own capital. Disabilities, illness, mortality are perceived as the loss in terms of the social health, causing significant economic losses. Naturally, investments in the health capital promote increasing the number of population capable of working, as well as reducing illness and death rate which in turn has a positive impact on a human capital.

Health determines the length of time a person is able to spend on working. A healthy person almost never misses any of the working days, therefore, he/she is more productive. Health reduces the number of the days of illness and the number of working days increases. It means that health production influences profitability of a person. A healthy person's satisfaction level as well as number of healthy days for work increase. It means the possibility of receiving incomes that is reflected on the growth of incomes.

In this respect, health status represents an important part of the human capital. A human being receives the familial initial health supply. But when the physical capital is damaged, the health capital may lose value day by day. Therefore, people invest in health aiming to make it better. It can be said that the health capital has an individual as well as social importance for a human being and society. According to Grossman, the health capital is given more significance as other goods and services are consumed in the modern era (5). Samuel Preston was the first who studied the relation of health condition with incomes per an individual (6). According to him, there is a positive relation between the national income level and life expectancy. Initially, the role of health in less developed countries was focused on. Health was considered as the way to escape poverty (7). Afterwards, when analyzing the difference between poor and rich countries, the role of health in terms of the economic growth was emphasized. Studies showed that health condition was much more important in the economic growth than education level $(8,9)$.

Improved health condition of population has a positive effect on economic productivity. Five main mechanisms are distinguished (10).

Productive, fruitful efficiency: Health and education together represent a factor that determines an individual's productivity and efficiency. Empirical evidence shows that healthy workers have a better physical and mental health and therefore are more productive $(11,12)$. Health also influences the labor provision as health problems become the reason for not being present at work (13). At the same time an individual with health problems may arrive at work but all his efforts may happen to be less productive.

Life expectancy: Improved health promotes improvement of the life expectancy. In turn, as people expect a long life, investments in education become more attractive and motivation of making more savings at the pension age also emerges (14). As a result, life expectancy growth encourages improvement of qualification of education and savings' level.

Life expectancy growth also has an impact on the demographic structure of the population. Reduction of the infant mortality rate and improvement of the life expectancy causes proportional growth of the worker population; but in the long-run perspective, an opposite effect is expected against the background of the birth rate reduction. In highly-developed countries, the birth rate reduction causes decrease of the employable population.

Ability to learn: Studies prove that improvement of the health condition promotes development of better cognitive abilities as well as skills and positive educational results $(15,16)$. The better an individual's health condition, the higher the cognitive skills are. Also, the level of being absence at school or work is lower and individuals are more able to absorb and accumulate knowledge.

Creativity: Better educational results achieved due to good health have a positive effect on creative and innovative activities. Educated people are good innovators and more flexible in terms of technological changes. Therefore, improvement of education accelerates technologic development. It can be concluded that healthy and educated workers respond to technological changes as well as innovative processes more easily; that represents a factor which determines successful implementation of changes.

Inequality: The different nature of the investments made in human capital causes different incomes. In this context, improvement of health may be considered as a tool for reduction of inequality of incomes. The lower the inequality between people's incomes, the more people will be allowed to finance their education and health needs that will further improve their economic condition. Considering that health and

East J Med Volume:24, Number:1, January-March/2019 
Table 1. Factors influencing health capital, Georgia

\begin{tabular}{|c|c|c|c|c|c|c|}
\hline & 1990 & 1995 & 2000 & 2005 & 2010 & 2015 \\
\hline $\begin{array}{l}\text { GDP per individual (current prices), } \\
\text { USD }\end{array}$ & 1614.6 & 569 & 692 & 1530.1 & 2964.5 & 3796 \\
\hline Human development index & - & - & 0.672 & 0.711 & 0.735 & 0.754 \\
\hline Life expectancy & 71 & 70 & 71.8 & 73.9 & 73.9 & 74.4 \\
\hline $\begin{array}{l}\text { Morbidity } \\
\text { Prevalence rate (per } 100000 \\
\text { population per year) }\end{array}$ & - & - & $\begin{array}{l}27006 . \\
5\end{array}$ & 35823.3 & $\begin{array}{l}49553 . \\
\quad 9\end{array}$ & 101154.1 \\
\hline $\begin{array}{l}\text { Morbidity } \\
\text { Incidence rate (per } 100000 \\
\text { population per year) }\end{array}$ & 22498.2 & 9077.5 & $\begin{array}{c}10623 . \\
8\end{array}$ & 15902.6 & $\begin{array}{c}26076 . \\
6\end{array}$ & 59677.3 \\
\hline Mortality rate per 1000 people & 9.6 & 7.8 & 10.7 & 9.3 & 10.6 & 13.2 \\
\hline $\begin{array}{l}\text { Infant mortality rate (probability of } \\
\text { dying by age } 1 \text { per } 1000 \text { live births) }\end{array}$ & 22 & 29 & 21.2 & 18.1 & 12 & 8.2 \\
\hline $\begin{array}{l}\text { Under-five mortality rate (probability } \\
\text { of dying by age } 5 \text { per } 1000 \text { live } \\
\text { births) }\end{array}$ & 47 & 34 & 27.2 & 19.4 & 13.4 & 11.9 \\
\hline $\begin{array}{l}\text { Maternal mortality ratio (per } 100000 \\
\text { live births) }\end{array}$ & 40.9 & 55 & 60 & 23.4 & 19.4 & 27.1 \\
\hline $\begin{array}{l}\text { Birth Rate }- \text { total number of live } \\
\text { births per } 1,000 \text { in a population }\end{array}$ & 14 & 11 & 10 & 10.7 & 10.7 & 15.9 \\
\hline $\begin{array}{l}\text { Outpatient referral rate per } \\
\text { individuals }\end{array}$ & - & 1.1 & 1.5 & 2.1 & 2.1 & 3.6 \\
\hline $\begin{array}{l}\text { General government expenditure on } \\
\text { health (mln GEL) }\end{array}$ & - & 31 & 61.7 & 194 & 414.8 & 656.2 \\
\hline $\begin{array}{l}\text { General government expenditure on } \\
\text { health as a percentage of total } \\
\text { government expenditure }\end{array}$ & - & 4.9 & 16.7 & 19.5 & 23.1 & 29.8 \\
\hline $\begin{array}{l}\text { General government expenditure on } \\
\text { health as a percentage of total } \\
\text { expenditure on health }(\%)\end{array}$ & - & 0.9 & 1.2 & 1.7 & 2 & 2.24 \\
\hline $\begin{array}{l}\text { Out-of-pocket healthcare } \\
\text { expenditures }(\%)\end{array}$ & - & 95 & 83.3 & 80.4 & 77 & 70 \\
\hline
\end{tabular}

\section{GEL Georgian Lari}

incomes are closely related to each other, reduction of inequality between incomes will cause reduction of inequality of health. Therefore, investment in the health sector will reduce inequality between incomes, increase labor productivity and promote economic growth.

Methodology: This study is based on the secondary sources of data. The data were collected in a period of 1990 to 2015. The data for this study were obtained from Human Development Report, Ministry of Labor, Health and Social Protection of Georgia (of various years). Economic growth of a country is determined by increase in the size of the economy of a nation. Commonly, economists measure economic output of a country through its Gross Domestic Product
(GDP). We have taken Gross Domestic Product as a dependent variable in our study. As a proxy indicator for measuring the health capital we used the life expectancy at birth, the general and initial illness rate, the general, maternal and children's mortality rate, outpatient referral rate, the state expenses on healthcare, the share of state expenditure in total expenditure on health, state expenditure on health as a percentage of the Gross Domestic Product.

\section{Discussion}

Georgia is a country in the Caucasus, located at the crossroads of Eastern Europe and Asia, with a population of almost 3.7 million (17). Georgia is a 
relatively new country, gaining independence after the collapse of the Soviet Union in 1991. According to World Bank statistics, Georgia is a lower-middle income country (18).

Since 2013, the Universal Healthcare Program (UHCP) has been enacted. The goals of UHCP are: to increase geographic and financial access to primary health care; to rationalize expensive and high-tech hospital services by increasing PHC utilization; and to increase financial access to urgent hospital and outpatient services (19).

Universal health care program covers: ambulatory consultations of a family physician, primary health care services, planned and urgent outpatient assistance, extended urgent hospitalization, planned surgeries (including daycare inpatient), treatment of oncological diseases, and child delivery.

In March 2017, the next wave of health care reforms was announced and this brought further differentiated packages for those covered under the UHCP. The most striking feature of this set of reforms was that the highest income group of around 43000 people was excluded from the UHCP from July 2017, as they are expected to purchase VHI [20]. Under the UHCP, the purchasing function has been consolidated to the Social Services Agency (SSA)

Georgia has made significant progress in improving access to health services under the UHCP (21). Financial protection has also improved and fewer households face financial hardship from having to pay for health services, but OOP payments still dominate health expenditure despite the rapid increase in public expenditure (30).

Health Capital and Georgia: The following factors influence formation of the health capital of population: illness of people, disabilities, mortality rate, life expectancy, healthcare expenses and outpatient referral rate (table 1).

According to the table, in the period of 1995-2015 GDP increased 6.7 times, that indicates the country's economic growth $(22,23,24,25,26)$. The human development index has increased by $12.2 \%$ in this period $(0.83 \%$ annual growth) and hit 0.754 by the year of 2015; According to the rate, Georgia is ranked $76^{\text {th }}$ among 188 countries (22).

The average life expectancy growth has had a positive impact on the country's economic growth. The same has been done by reduction of maternal and children's mortality rate and higher state expenses on healthcare.
According to some scholars, the rate of life expectancy is characterized by certain stagnation in the last decade (27).

Infant mortality rate (probability of dying by age 1 per 1000 live births) decreased from 22 to 8.2 in 1990-2015 and under-five mortality rate (probability of dying by age 5 per 1000 live births)-from 47 to 11.9 (22). For comparison, under-five mortality rate (probability of dying by age 5 per 1000 live births) is 11.3 in Europe [22].

Maternal mortality rate (per 100000 live births) dropped from 41 to 27.1 in 1990-2015. For comparison, maternal mortality rate (per 100000 live births) in Europe is 16 [22].

General government expenditure on health has increased in recent 25 years, and almost doubled in the latest 3 years; that has a positive impact on the population's health. But, despite these, Georgia is still significantly lagging behind the threshold set by the WHO recommendations as well as the rates of many poor countries with low incomes [28].

According to the World Health Organization, the government expenditure on health should constitute at least $15 \%$ of total state expenditure. Although government expenditure on health have significantly increased in Georgia, they are still very low in respect of the state budget reaching $6.9 \%$ only (28). This rate is almost twice less than the recommendations by WHO, while it constitutes $15-20 \%$ in the developed countries (28).

According to WHO recommendations, state expenditures on health should represent more than $40 \%$ in total healthcare expenditures. State expenditures on health care in Georgia represents $29,8 \%$ of the total expenses on healthcare, thus Georgia is far below the recommendations of the WHO [28]. Unlike Georgia, the following countries have crossed the threshold: Armenia (41.7\%), Kazakhstan (53.1\%), Ukraine (54.5\%), Kyrgyzstan (59\%); As for China, Lithuania, Turkey, Germany, Japan, this rate is relatively $55.8 \%, 66.6 \%, 77.4 \%, 76.8 \%, 82.1 \%$ [22]. Due to all above mentioned, Georgian people have to pay by themselves for healthcare issues (up to $70 \%$ ) $(28,29)$.

Outpatient referral rate increased from 1.1 to 3.6 per person as the state expenses increased, that positively reflects on the population's health condition (30). But this rate is still less than that of European countries ( 7.5 per person), which is caused by the circumstance that patients are less motivated to go to a doctor for prevention and

East J Med Volume:24, Number:1, January-March/2019 
decide to receive medical service only when they are in critical condition (31). Patients prefer hospital service $(32,33)$. According to the Ministry of Health, only $50.9 \%$ of the patients have referred to the primary healthcare facilities [34. All this shows that the primary healthcare system cannot fulfill the role of the so-called 'gatekeeper'. In general, the primary healthcare system has not developed in Georgia $(35,36,37,38)$.

The average life expectancy has increased for recent 25 years. The maternal and children's mortality rate has decreased, healthcare expenses have become higher and outpatient referral rate has also become of more constant character. All these have a positive influence on the people's health as well as country's economic growth. However, the state expenses on healthcare and outpatient referral rate is far below the European level. As the health capital fulfills significant role in terms of the country's economic growth in a long-run perspective, it is highly advisable to promote the development of the primary healthcare system and taking WHO recommendations concerning state healthcare expenses into account.

Declaration of Competing Interests: The authors declare that they have no competing interests.

Funding: This work was supported by Shota Rustaveli National Science Foundation of Georgia (grant number FR17_101).

\section{References}

1. McConnell C, Brue S, Flynn S. Economics: Principles, Problems, and Policies. McGrawHill Education 2011.

2. Schultz T. Investment in Human Capital. The American Economic Review 1961; 51: 1-17.

3. Becker G. Human Capital. Columbia University Press, New York 1975.

4. Becker G. Human capital: a theoretical and empirical analysis with special reference to education, 2nd ed. New York, National Bureau of Economic Research. 1975.

5. Grossman M. The demand for health: a theoretical and empirical investigation. New York, Columbia University Press. 1972.

6. Preston S. The Changing Relation between Mortality and the Level of Economic Development. Population Studies 1975; 29: 231-248.

7. Sala-i-Martin X. On the Health Poverty-Trap. Health and Economic Growth: Findings and
Policy Implications. Cambridge: The MIT Press 2005.

8. Barro R. Health and Economic Growth, Mimeograph. Pan American Health Organization 1996.

9. Knowles S, Owen P. Education and Health in an Effective-Labour Empirical Growth Model. The Economic Record 1997; 73: 314-328.

10. Howitt P. Health, Human Capital and Economic Growth: A Schumpeterian Perspective. Cambridge: The MIT Press 2005.

11. Shultz T. Productive Effects of Health. Cambridge: The MIT Press 2005.

12. Cai L, Kalb G. Health Status and Labour Force Participation: Evidence from Australia. Health Economics 2006; 15: 241-261.

13. Bloom D, Canning D. Population Health and Economic Growth, Commission on Development and Growth. World Bank Working Paper 2008; 24.

14. Kalemli-Ozcan S, Ryder H, Weil D. Mortality Decline, Human Capital Investment and Economic Growth. Journal of Development Economics 2000; 62: 1-23.

15. Miguel E. Health, Education and Economic Development. Health and Economic Growth: Findings and Policy Implications. Cambridge: The MIT Press 2005.

16. Case A, Fertig A, Paxson C. The Lasting Impact of Childhood and Circumstance. Journal of Health Economics 2005; 24: 365389.

17. National Statistics Office of Georgia. Population. 2018.

18. The World Bank. New country classifications by income level: 2018-2019.

19. Ministry of Labor, Health and Social Affairs (2014) Expectations always exceed the reality in healthcare.

20. Richardson E, Berdzuli N. Georgia: Health system review. Health Systems in Transition 2017; 19: 1-90.

21. Sehngelia L, Pavlova M, Groot W. Impact of Healthcare Reform on Universal Coverage in Georgia: A Systematic Review. Diversity and Equality in Health and Care 2016; 13: 349-356.

22. Human Development Report. United Nations Development Programme. 2015.

23. Silagadze A. Post-Soviet paradoxes of unemployment rate. Bulletin of the Georgian National Academy of Sciences 2017; 11: 136141.

24. Silagadze A. History of Georgian economic thought: relation between the center and the region. Bulletin of the Georgian National Academy of Sciences 2017; 11: 138-143.

25. Papava V. The problem of the catch-up effect and post-crises economic growth in the 
world leading countries. Bulletin of the Georgian National Academy of Sciences 2016; 10: 97-104.

26. Verulava T. Pension System in South Caucasus: Challenges and Reform Options. Bulletin of the Georgian National Academy of Sciences 2018; 12: 143-150.

27. Maghlapheridze N, Chodrishvili M. Average Life Expectancy Changes Analysis in Georgia. Report of Public Policy Research and Training Center Policy. Third Edition. Ilia State University 2014.

28. Verulava T, Maglakelidze T. Health Financing Policy in the South Caucasus: Georgia, Armenia, Azerbaijan. Bulletin of the Georgian National Academy of Sciences 2017; 11: 143150.

29. Asatiani M, Verulava T. Georgian Welfare State: Preliminary Study Based on EspingAndersen's Typology. Economics and Sociology 2017; 10: 21-28.

30. Verulava T, Jorbenadze R, Barkalaia T. Introduction of universal health program in Georgia: Problems and Perspectives. Georgian Medical News 2017; 262: 116-120.

31. Verulava T, Jincharadze N, Jorbenadze R. Role of Primary Health Care in Rehospitalization of Patients with Heart Failure. Georgian Medical News 2017; 264: 135-139.

32. Verulava T, Gabuldani M. Accessibility of Urgent Neurosurgery Diseases by the State Universal Healthcare Program in Georgia (country). Gazi Medical Journal 2015; 26: 4245.
33. Verulava T, Jorbenadze R., Karimi L., Dangadze B, Barkalaia T. Evaluation of Patient Satisfaction with Cardiology Services. The Open Public Health Journal 2018; 11: 201-208.

34. Verulava T, Sibashvili N. Accessibility to Psychiatric Services in Georgia. Journal of Psychiatry: Open Access 2015; 18: 1-5.

35. Gotsadze G, Wenze T, Shengelia N, Zoidze A. Determinants analysis of outpatient service utilisation in Georgia: Can the approach help inform benefit package design? Health Research Policy and Systems 2017; 15: 15-36.

36. Verulava T, Kachkachishvili I, Abulashvili S, Chkhaidze M, Khuroshvili M, Kiknadze L, Jorbenadze R. Students' Awareness, Knowledge, and Behavior Regarding HIV/AIDS. Gazi Medical Journal 2018; 29: 215-218.

37. Verulava T, Khuchua L, Kachkachishvili I, Jorbenadze R. Knowledge of Sexually Transmitted Infections Among Homeless People in a Municipal Shelter. International Quarterly of Community Health Education 2018; 38(4):245-249.

38. Verulava T, Grdzelishvili A, Magaldadze M, Makharashvili A, Chibukhaia G, Jorbenadze R, Dangadze B. Social problems of Alzheimer's patients and their family members. Home Health Care Management \& Practice 2018; 30: 175-178. 